\title{
水理模型実験における柱状粗度の拡散効果について \\ THE EFFECT OF ROUGHNESS BARS ON TRANSVERSE MIXING IN HYDRAULIC MODELS
}

\author{
早川典生* · 白山昌義** - 中村由行*** - 福嶋祐介**** \\ By Norio HAYAKAWA, Masayoshi SHIRAYAMA, Yoshiyuki NAKAMURA \\ and Yuusuke FUKUSHIMA
}

\begin{abstract}
Similarity of horizontal diffusion in hydraulic models is generally difficult to achieve because the diffusion law is often not known and small scale ratio is often used. It is generally accepted that use of roughness elements is necessary to generate turbulence in the small-scale hydraulic models. Quantitative assessment of such roughness elements, e. g. roughness bars or strips, with regard to the horizontal diffusion, however, has not been studied extensively. In this paper, a flume study is carried out to obtain the velocity defect law in the presence of roughness bars. Based on the obtained velocity defect law, the horizontal turbulent diffusivity is derived using the Prandtl's concept of mixing length and the Reynolds' analogy. Experimentally verified law of horizontal diffusivity thus is expressed in terms of flow velocity, radius of the bar elements and spacings of roughness bars in two horizontal directions.
\end{abstract}

Keywords: hydraulic model, roughness, transverse mixing

\section{1.はじめに}

海洋拡散の予測手法の 1 つとして水理模型実験が挙げ られる. その際対象領域の大きさゆえに，ひずみ模型が 用いられることが多い。この場合, 現地と模型の流れの 相似性を保つために，以下の無次元数が両者の間で一致 しなければならない.

$$
F=U / \sqrt{g Y}, g L / C^{2} Y
$$

ここで, $U$ は水平方向平均流速, $Y$ は鉛直方向代表長さ, $L$ は水平方向代表長さ， $C$ は Chezy の係数である. 一 般に小縮尺の模型では人工付加粗度を与えることにより 式（1）の無次元数を一致させ得ることが理論および実 験で示されている1).

このような水理模型の拡散現象の相似則については, 樋口 ${ }^{2)}$ による, 水平拡散にリチャードソン・オズミドフ 則を仮定し，鉛直縮尺を水平縮尺の $2 / 3$ 乗とすることに より相似させる方法が提案されているが, 一方で拡散法 則をレイノルズ相似と対数速度分布則により導かれるも のとすると, ひずみ模型では拡散の相似は得られないこ

* 正会員 $\mathrm{Ph}$. D. 長岡技術科学大学教授 建設系 ( $\bar{\top} 940-21$ 長岡市上富岡町 1603-1)

** 正会員 工修 (財) 建設技術研究所

*** 正会員 工修 長岡技術科学大学助手 建設系

**** 正会員 工博 長岡技術科学大学助教授 建設系
とも知られている3 . 一般には, 沿岸海洋域の拡散現象 を支配する法則は明らかではなく，また小縮尺の模型で は乱れが十分でないことが予測されるので, 粗度として 柱状粗度を用いて経験的に拡散を相似させる方法がとら れる4．しかしながら，粗度による拡散効果は定量的に 解明されておらず，実験においては試行錯誤的に粗度の 配置が定められているのが現状である．柱状粗度の水平 拡散効果に関する研究は少なく, 唯一Fischer $ら^{5)}$ によ るものがあるだけである.しかし彼らの解析は十分なも のではなく実用上に困難を残している．本論文では柱状 粗度の拡散効果を理論的および実験的に明らかにして， 拡散現象の相似技術の確立を図るものである.

\section{Fischer らの解析についで5}

Fischer らの解析では，流れに対する抵抗はすべて粗 度が受け持つと考えて, 粗度要素間の流速分布は放物線 であると仮定し，レイノルズ相似の下に横方向拡散係数 $\varepsilon$ の表示式として次式を得た注1).

$$
\varepsilon=0.075 d U \lambda / \omega
$$

注 1) 本論文で用いられている拡散係数 $\varepsilon, \varepsilon_{z}$ は保存物質濃 度 $C$ に関する次式の乱流拡散方程式に現われる $\varepsilon, \varepsilon_{z}$ である.

$$
\frac{\partial C}{\partial t}+U \frac{\partial C}{\partial x}=\varepsilon_{x} \frac{\partial^{2} C}{\partial x^{2}}+\varepsilon \frac{\partial^{2} C}{\partial y^{2}}+\varepsilon_{z} \frac{\partial^{2} C}{\partial z^{2}}
$$


ここで， $d$ は粗度径， $\lambda$ は流れに直角方向の粗度間隔， $\omega$ は流下方向の粗度列間隔である. なお Fischer らは式

（2）を導くに際して，粗度は流れに直角格子状に配置 されたものと仮定している.

式 (2) では, $d, U$ が一定であれば, $\lambda$ および $\omega$ が いかなる大きさでもその比 $(N \omega)$ が一定であるかぎり， $\varepsilon$ は常に一定となる. しかしながらこの結果には次元解 析的に無理がある.すなわち $\varepsilon$ は無次元表示をすれば, 次式のように表わされる.

$$
\varepsilon / \lambda U=f(d / \lambda, \omega / \lambda)
$$

式（2）を式（3）に現われる無次元数で図示したのが Fig. 1 である. 図には3.で述べる $d / \lambda$ を変えた拡散実験 結果（Table 2) も示した.

Fig. 1 によると相対粗度径 $d / \lambda$ が小さい場合には, Fischer らの解析結果と実験結果は良好な一致を示して はいるが， $d / \lambda$ が大きくなると実験値は解析結果を外 れて大きな值をとっている.これは式（2）が式（3) の右辺の関数形に含まれている二無次元数の比に比例す

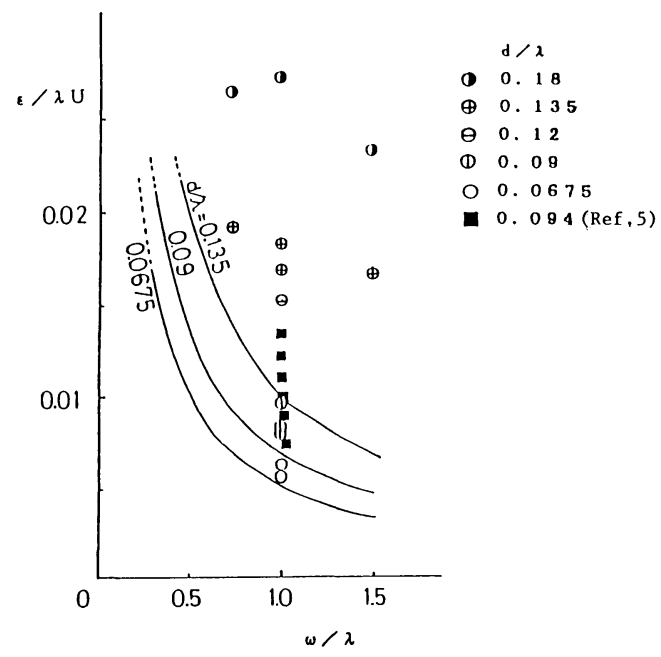

Fig. 1 Fischer's Prediction and Experimental Results.
るという，単純すぎる形をとっている結果であり，解析 の基本にある流速分布形や流れの抵抗則がすべて粗度に より受け持たれるという仮定に無理があることを示唆し ている.

\section{3. 実験}

Fischer らの解析の検討に基づいて, $d / \lambda, \omega / \lambda$ を変 えた実験を行い，流速分布形を求めるとともに，染料を 用いた拡散実験を行った。実験装置は, 長さ $9 \mathrm{~m}$, 幅 $40 \mathrm{~cm}$, 可変勾配の開水路である. 壁面のマニングの粗 度係数は 0.014 である. 粗度要素としては水面に達する 長さの, 径 $1.8 \mathrm{~cm}$ の塩化ビニールパイプを千鳥状に水 路底に植え付けた．実験条件は Table 1 に示すようであ る.ここで表中の摩擦速度 $u_{*}$ は流れがほぼ等流である

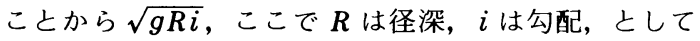
計算した。

測定項目は流速測定と染料濃度測定である．流速測定 は超小型プロペラ流速計（篠塚製作所製 SV-3）を用 いた。 染料濃度測定では濃度 $800 \mathrm{ppm}$ のメチレンブルー 溶液を，流れが十分一様になった断面の水路中央の水表 面から（ただし Run 1 ３では $1 / 2$ 水深点から）連続 放流し，染料放流位置からTable 1 に Lで示した59 $67 \mathrm{~cm}$ 下流の断面において式料をサイフォン採水した。 試料は濁度計を用いて濃度測定し，断面平均の染料雲の 横方向分散 $\left(\sigma^{2}\right)$ を求め, 次式により横方向拡散係数を 計算した。

$$
\varepsilon=\frac{1}{2} \sigma^{2} U / L
$$

ここで, $\varepsilon$ は横方向拡散係数, $\sigma^{2}$ は染料雲の分散, $U$ は平均流速， $L$ は染料放流位置から濃度測定位置まで の距離である．また $\sigma^{2}$ は各水深ごとの濃度分布測定值 から濃度の分散值を求め, それを平均することにより求 めた。

測定結果の一例を Fig. 2 に示す.（a ）は流速分布， （b ）は染料の初期濃度で無次元化した濃度分布である.

\begin{tabular}{|c|c|c|c|c|c|c|c|c|c|c|}
\hline Run No. & $\begin{array}{l}\text { 水深 } \\
(\mathrm{c} \text { 田 }\end{array}$ & (流量 & $\left(\begin{array}{c}\mathrm{u} / \mathrm{s} \\
(\mathrm{cm} / \mathrm{s})\end{array}\right.$ & $\underset{(\mathrm{cm} / \mathrm{s})}{U}$ & $\begin{array}{l}\lambda \\
(\mathrm{cm})\end{array}$ & $\omega / \lambda$ & $\underset{(\mathrm{cm})}{\mathrm{d}}$ & $\mathrm{d} / \lambda$ & $\underset{(\mathrm{cm})}{\mathrm{L}}$ & \multirow{5}{*}{$\begin{array}{c}\underbrace{}_{0} \\
0 \\
0 \\
0 \\
0\end{array}$} \\
\hline $\begin{array}{l}1 \\
2 \\
3\end{array}$ & $\begin{array}{l}4.5 \\
8.5 \\
8.5\end{array}$ & $\begin{array}{l}1.88 \\
4.92 \\
6.96\end{array}$ & $\begin{array}{l}0.671 \\
0.854 \\
1.208\end{array}$ & $\begin{array}{l}10.8 \\
14.7 \\
21.0\end{array}$ & $\begin{array}{l}26.66 \\
26.66 \\
26.66\end{array}$ & $\begin{array}{l}1 \\
1 \\
1\end{array}$ & $\begin{array}{l}2.4 \\
1.8 \\
1.8\end{array}$ & $\begin{array}{l}0.09 \\
0.0675 \\
0.0675\end{array}$ & $\begin{array}{l}61 \\
61 \\
61\end{array}$ & \\
\hline $\begin{array}{l}4 \\
5 \\
6\end{array}$ & $\begin{array}{l}4.5 \\
8.5 \\
8.5\end{array}$ & $\begin{array}{l}1.88 \\
4.92 \\
6.96\end{array}$ & $\begin{array}{l}0.671 \\
0.854 \\
1.208\end{array}$ & $\begin{array}{r}9.5 \\
12.6 \\
19.0\end{array}$ & $\begin{array}{l}13.33 \\
13.33 \\
13.33\end{array}$ & $\begin{array}{l}1 \\
1 \\
1\end{array}$ & $\begin{array}{l}2.4 \\
1.8 \\
1.8\end{array}$ & $\begin{array}{l}0.18 \\
0.135 \\
0.135\end{array}$ & $\begin{array}{l}67 \\
67 \\
67\end{array}$ & \\
\hline $\begin{array}{l}7 \\
8 \\
9\end{array}$ & $\begin{array}{l}4.5 \\
8.5 \\
8.5\end{array}$ & $\begin{array}{l}1.88 \\
4.92 \\
6.96\end{array}$ & $\begin{array}{l}0.671 \\
0.854 \\
1.208\end{array}$ & $\begin{array}{r}9.0 \\
12.3 \\
19.0\end{array}$ & $\begin{array}{l}20 \\
20 \\
20\end{array}$ & $\begin{array}{l}1 \\
1 \\
1\end{array}$ & $\begin{array}{l}2.4 \\
1.8 \\
1.8\end{array}$ & $\begin{array}{l}0.12 \\
0.09 \\
0.09\end{array}$ & $\begin{array}{l}64 \\
64 \\
64\end{array}$ & \\
\hline $\begin{array}{l}10 \\
11 \\
12\end{array}$ & $\begin{array}{l}4.5 \\
8.5 \\
8.5\end{array}$ & $\begin{array}{l}1.88 \\
4.92 \\
6.96\end{array}$ & $\begin{array}{l}0.671 \\
0.854 \\
1.208\end{array}$ & $\begin{array}{r}9.6 \\
13.1 \\
19.7\end{array}$ & $\begin{array}{l}13.33 \\
13.33 \\
13.33\end{array}$ & $\begin{array}{l}1.5 \\
1.5 \\
1.5\end{array}$ & $\begin{array}{l}2.4 \\
1.8 \\
1.8\end{array}$ & $\begin{array}{l}0.18 \\
0.135 \\
0.135\end{array}$ & $\begin{array}{l}64 \\
64 \\
64\end{array}$ & \\
\hline $\begin{array}{l}13 \\
14\end{array}$ & $\begin{array}{l}4.5 \\
8.5\end{array}$ & $\begin{array}{l}4.92 \\
6.96\end{array}$ & $\begin{array}{l}0.671 \\
0.854\end{array}$ & $\begin{array}{r}7.6 \\
11.6\end{array}$ & $\begin{array}{l}13.33 \\
13.33\end{array}$ & $\begin{array}{l}0.75 \\
0.75\end{array}$ & $\begin{array}{l}2.4 \\
1.8\end{array}$ & $\begin{array}{l}0.18 \\
0.135\end{array}$ & $\begin{array}{l}59 \\
59\end{array}$ & \\
\hline
\end{tabular}

Table 1 Experimental Conditions. 


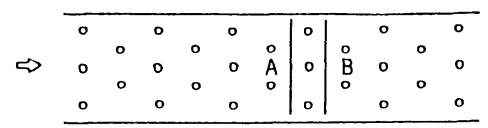

Run 4

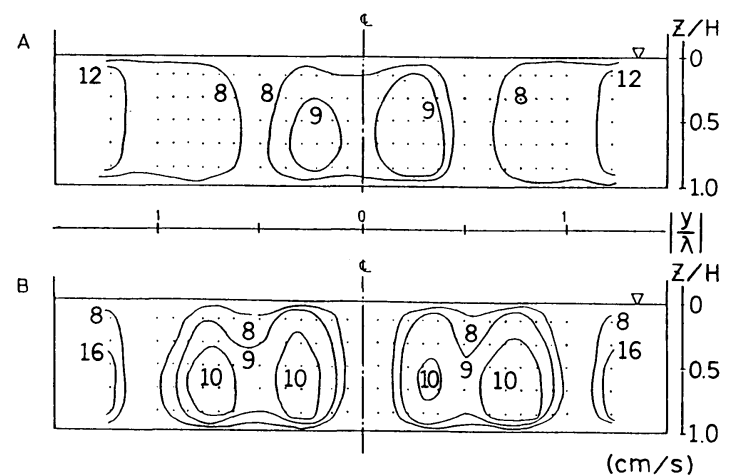

いこと，またさらに一列上流側の粗度の背後に あたる位置でも減衰していることがわかる．ま た Fig.2（b ）より濃度分布は，水路中央を軸 として対称形となっており, 粗度により発生し た乱れにより十分に断面内に拡散していること を示している. 図でRun 1 は $1 / 2$ 水深点から 染料を放流した場合であるが，水表面から放流 した例の Run 4 との差は僅少である.

拡散実験の結果を Table 2 に示す．表におい $\tau \varepsilon_{z}$ は，染料濃度の鉛直分布形に次式の理論 解( ${ }^{6}$ が合うように逆算して求めた鉛直拡散係数 である.

$$
\frac{C}{C_{0}}=\frac{q}{2 \pi\left(\varepsilon_{y} \varepsilon_{z}\right)^{1 / 2}|x|} \exp \left(-\frac{U}{4 x}\left(\frac{y^{2}}{\varepsilon_{y}}+\frac{z^{2}}{\varepsilon_{z}}\right)\right)
$$

Fig. 2 (a) Isovels for Run 4.
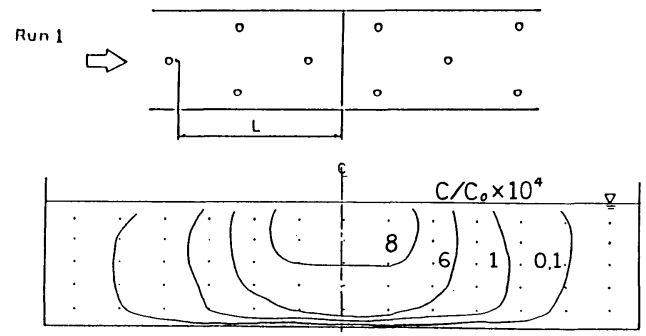

Run 4
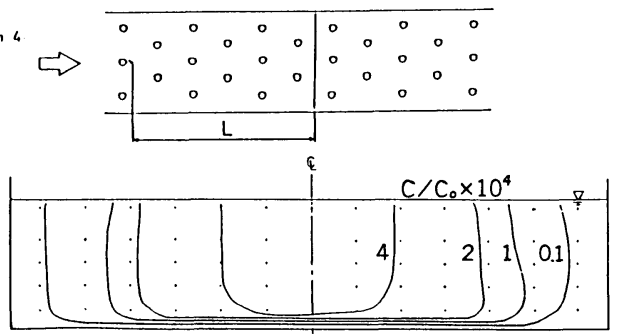

Fig. 2 (b) Equi-concentration Lines for Run 1 and 4 .

図中の黒点は断面内の測定点を示す. Fig. 2 (a ) より 流速は測定断面のすぐ上流側の粗度の背後で減衰が著し
ここで, $C$ は染料濃度, $C_{0}$ は染料初期濃度, $q$ は染料 の流量, $x$ は流下距離, $y$ は横方向距離, $z$ は水面から の深さである. 式（5）は拡散幅が無限の拡がりを有す る場合の解であるが, 本問題のように幅 $b$, 水深 $h$ の 水路中に拡散する場合には, 式 $(5)$ は $\exp \left(-U h^{2} / L \varepsilon\right)$ および $\exp \left(-U b^{2} / 4 L \varepsilon\right)$ の誤差を与えることを示す ことができる. 本問題ではこのうち前者の值が 0.1 0.3 程度になるが, ここでは $\varepsilon_{z}$ のおおよその值を求め, 式（6）と比較することが目的なのでこの式を用いた。

Fischer ${ }^{4}$ によれば粗度がない場合の拡散係数は

$\varepsilon=\alpha h u_{*}$

で表わされる.ここで $h$ は水深， $u_{*}$ は摩擦速度である. 比例定数 $\alpha$ の值は水平拡散では 0.15 , 鉛直拡散では 0.07 である.

Table 2によれば, 柱状粗度のある本実験では, 式 ( 6 ) の $\alpha$ は粗度のない場合よりも2 10 倍程度大きく，し かも水平拡散と鉛直拡散で同程度の値となっている.こ のことより,粗度のある場合の拡散現象の機構は,式 (6) の場合と異なること, また粗度により拡散が助長されて いることがうかがえる.
Table 2 Measured Diffusivities.

\begin{tabular}{c|c|c|c|c|c|c}
\hline Run No. & $\begin{array}{c}\varepsilon \\
\left(\mathrm{cm}^{2} / \mathrm{s}\right)\end{array}$ & $\begin{array}{c}\varepsilon z \\
\left(\mathrm{~cm}^{2} / \mathrm{s}\right)\end{array}$ & $\varepsilon / \mathrm{h} \mathrm{c}$ & $\varepsilon / \lambda \mathrm{U}$ & $\varepsilon=/ \mathrm{hu}$ & $\varepsilon z / \lambda U$ \\
\hline 1 & 2.37 & 1.5 & 0.79 & 0.00808 & 0.21 & 0.0052 \\
3 & 2.50 & 10 & 0.34 & 0.00617 & 1.38 & 0.0255 \\
& 3.31 & 14 & 0.32 & 0.00575 & 1.36 & 0.0250 \\
\hline 4 & 3.51 & 3.0 & 1.16 & 0.02742 & 0.99 & 0.0238 \\
5 & 2.83 & 1.7 & 1.74 & 0.01685 & 0.23 & 0.0101 \\
6 & 4.57 & 2.6 & 0.45 & 0.01823 & 0.25 & 0.0102 \\
\hline 7 & 2.47 & 1.8 & 0.91 & 0.01522 & 0.60 & 0.0100 \\
8 & 2.35 & 1.5 & 0.32 & 0.00955 & 0.21 & 0.0061 \\
9 & 3.11 & 2.6 & 0.30 & 0.00818 & 0.25 & 0.0069 \\
\hline 10 & 3.02 & 2.1 & 1.00 & 0.02357 & 0.70 & 0.0164 \\
11 & 2.93 & 2.3 & 0.40 & 0.01678 & 0.32 & 0.0132 \\
12 & 4.41 & 2.1 & 0.43 & 0.01675 & 0.21 & 0.0080 \\
\hline 13 & 2.68 & 1.8 & 0.89 & 0.02648 & 0.60 & 0.0178 \\
14 & 2.99 & 1.6 & 0.41 & 0.01928 & 0.22 & 0.0103 \\
\hline
\end{tabular}

\section{4. 柱状粗度の拡散効果につい $\tau$}

\section{（1）流速分布}

柱状粗度のある流れの拡散係数の表 示式を得るためには, 流速分布の表示 式を求める必要がある. 柱状粗度のあ る流れの流速分布は非常に複雑である ので, 主として実験により，流速分布 表示式を導いた。 3.で述べたような千 鳥状多列の柱状粗度のある流れの流速 分布は, 粗度を一列配置した場合の後 
流の流速分布の重ね合わせであると考えられる．一列配 置した場合の後流の流速分布は Schlichting ${ }^{7}$ により与 えられているが, その式は, $x / \lambda>4$ という粗度から離 れた領域に適用されるので, 本研究の対象とするような, 粗度近傍の後流の流速分布は実験的に求めた.

実験は前述の開水路に $d=1.8 \mathrm{~cm}$ の粗度を一列に粗 度間隔 $\lambda=13.3 \mathrm{~cm}$ に設置し, 流量を 3 段階に変化させ, それぞれの条件下で流下方向に $\lambda$ の $0.25 ， 0.5 ， 1 ， 2$, 4 倍の断面で流速を測定した. 実験条件を Table 3 に示 す. Fig. 3 は流速分布の概形と特性値を示したものであ り, $U$ は平均流速, $b / 2$ は流速 $u$ が $U$ となる横方向座 標 $y$ の値, $u_{\min }$ は最小流速, $v=u-u_{\min }, V_{\max }$ は $V$ の最大値である．以下にこれらの特性値を用いて測定値 を整理する。

Fig. 4 は測定した全流速値を無次元表示したものであ り,この図より流速分布形状は, 流下距離, 平均流速に

Table 3 Experimental Conditions for a single Row of Roughness Bars.

\begin{tabular}{c|c|c|c|c|}
\hline RUN no. & $q(1 / \mathrm{s})$ & $\mathrm{i}$ & $\mathrm{h}(\mathrm{cm})$ & $\mathrm{U}(\mathrm{cm} / \mathrm{s})$ \\
\hline 1 & 1.88 & $1 / 8000$ & 1.5 & 13.4 \\
\hline 2 & 6.96 & $1 / 4000$ & 8.5 & 25.0 \\
\hline 3 & 10.7 & $1 / 2000$ & 9.0 & 37.0 \\
\hline
\end{tabular}

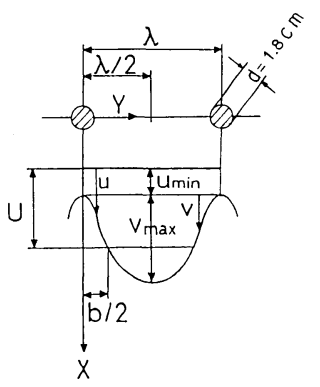

Fig. 3 Definition Sketch of Wake Flow behind a Row of Roughness Bars.

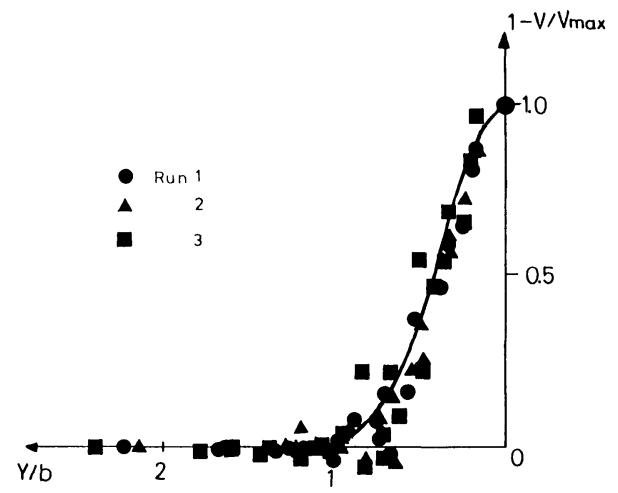

Fig. 4 Similarity of Velocity Profiles behind a Row of Roughness Bars.
関係なく次式のように Gauss 分布で表わされる.

$$
\frac{v}{V_{\max }}=1-\exp \left(-\frac{(y / b)^{2}}{0.21}\right) \cdots
$$

この式を用いて流速分布形を表わすためには最大流速, 平均流速の流下方向減衰と後流幅 $b$ の流下方向の変化 を求める必要があり,これらはおのおの Fig. 5，6，7に 示すようである. Fig. 5，6に示す直線関係を用いて得 られた流速分布式を以下に示す。

$$
\begin{aligned}
\frac{u}{U}= & 1-0.235\left[\frac{x-d / 2}{\lambda}\right]^{-2 / 3}+0.35\left[\frac{x-d / 2}{\lambda}\right]^{-1 / 2} \\
& {\left[1-\exp \left[-\frac{(y / b)^{2}}{0.21}\right]\right] \cdots \cdots \cdots \cdots \cdots \cdots \cdots \cdots \cdots(8) \cdots \cdots \cdots \cdots \cdots \cdots }
\end{aligned}
$$

ただし後流幅 $b$ はFig. 7 より以下のようである.

$$
\begin{aligned}
& \frac{b}{\lambda}=0.39\left(\frac{x-d / 2}{\lambda}\right)^{1 / 3}: \frac{x-d / 2}{\lambda}<2.2 \cdots \cdots \cdots(9 \cdot \mathrm{a}) \\
& =0.5 \quad: \quad>2.2
\end{aligned}
$$

なお単円柱後流の流速分布はよく研究されているが7),

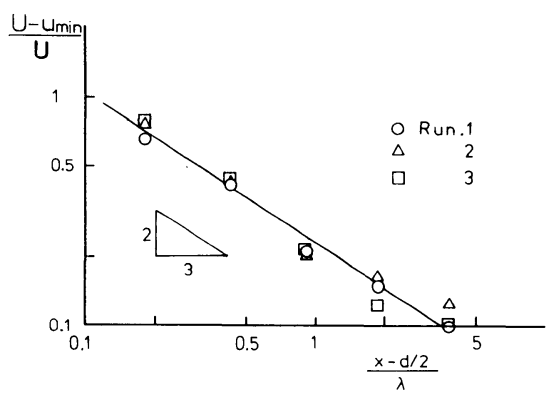

Fig. 5 Decay of Average Excess Velocity.

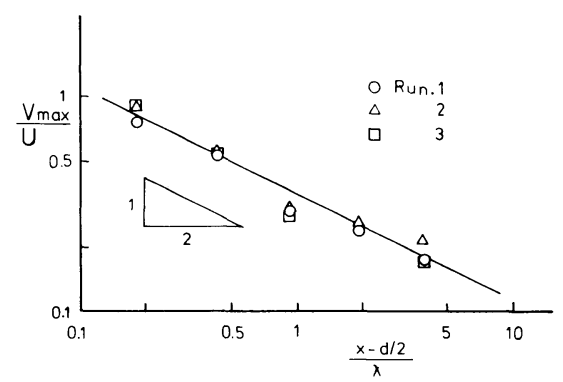

Fig. 6 Decay of the Excess Maximum Velocity.

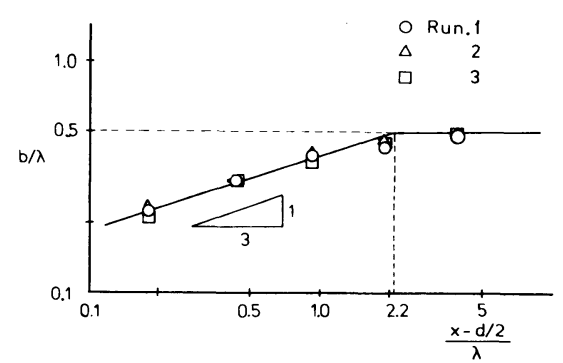

Fig. 7 Width of Wake. 
その結果は次式のように書ける.

$$
1-\frac{u}{U_{\max }} \propto\left(\frac{x}{d}\right)^{-1 / 2} \exp \left\{-y^{2} / b^{\prime 2}\right\}, \quad b^{\prime} \propto(d x)^{1 / 2}
$$

ところで式（8）をこの式と比較しやすいように書き改 めると次式のようになる.

$$
1-\frac{u}{U_{\max }}=0.35 \frac{U}{U_{\max }}\left(\frac{x-d / 2}{\lambda}\right)^{-1 / 2} \exp \left\{\frac{-(y / b)^{2}}{0.21}\right\}
$$

このように式（8）は単円柱後流の場合との類似点はみ られるが, $d / \lambda \rightarrow 0$ の極限で必ずしも両者は一致しない. これは本研究では円柱近傍を問題にしていること, また 円柱レイノルズ数が 1000 程度と小さいことであるため と思われる.

粗度を Fig. 8 のように千鳥に配置したときの流速分布 は,Fig. 2 ( a ) の実験結果を参照して以下の仮定の下 に導いた。（1）任意の断面の流速分布を支配する粗度 列は，すぐ上流側の粗度列とさらに一列上流側の粗度列

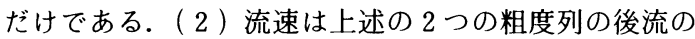
重ね合わせで表現できるものとする。これより，Fig. 8 の断面（太線）における流速は式（8），（9）を用いて 次のように書ける.

ただし後流幅 $b$ については式 $(9 \cdot a)$ の条件を満たし ているものとした.

$$
\begin{aligned}
\frac{u}{U}= & 1-0.235\left[\left[\frac{x-d / 2}{\lambda}\right]^{-2 / 3}+\left[\frac{x+\omega-d / 2}{\lambda}\right]^{-2 / 3}\right] \\
& +0.35\left[\left[\frac{x-d / 2}{\lambda}\right]^{-1 / 2}\right. \\
& {\left[1-\exp \left[-\frac{(y / \lambda)^{2}((x-d / 2) / \lambda)^{-2 / 3}}{0.21 \times 0.39^{2}}\right]\right.} \\
& +\left[\frac{x+\omega-d / 2}{\lambda}\right]^{-1 / 2} \\
& {\left[1-\exp \left[-\frac{(5-y / \lambda)^{2}((x+\omega-d / 2) / \lambda)^{-2 / 3}}{0.21 \times 0.39^{2}}\right]\right] }
\end{aligned}
$$

Fig. 9 は式（10）と実験結果を比較した例であり，良 好な一致を示している. 本実験の実験範囲 $\left(0.21<F_{r}\right.$ $\left.<0.39,5 \times 10^{3}<R_{e}<2.9 \times 10^{4}\right)$ では式（10）は実験結

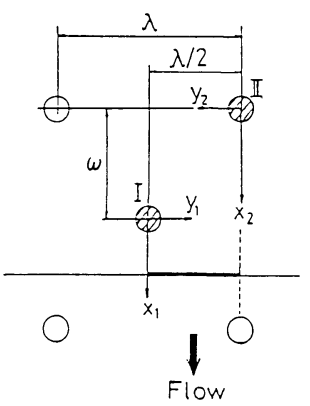

Fig. 8 Definition Sketch for Staggered Roughness Bars.

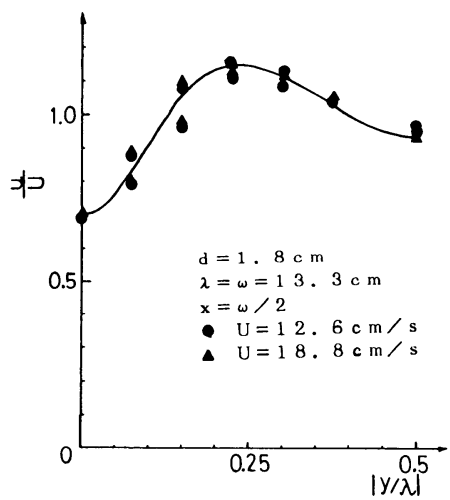

Fig. 9 Predicted Velocity Profile and Experimental Data.

果をよく説明することが確認された。

\section{(2) 拡散係数の表示式}

柱状粗度のある流れにおける水平方向（横方向）拡散 係数の算定を，噴流や後流の場合に用いられる渦動粘性 係数に関する Prandtl の混合距離理論を用い,レイノル ズ相似を仮定して行った. すなわちその式は次のようで ある。

$$
\varepsilon=\varkappa\left(u_{\max }-u_{\min }\right) w
$$

ここで $u_{\max }, u_{\min }$ は横方向のおのおの最大, 最小流速, $w$ は流速分布から決定される混合領域の幅, $x$ は通常は 実験定数である．粗度を千鳥状に配置した場合，Fig. 10 のように $2 つ の$ 後流の影響が考えられるので，ここでは 図に示す後流幅 $w_{1}, w_{2}$ を重みにした平均値として拡散 係数を次のように表わした.

$$
\varepsilon=x\left[\frac{\left(u_{\max }-u_{\min _{2}}\right) w_{1}^{2}+\left(u_{\max }-u_{\min 2}\right) w_{2}^{2}}{w_{1}+w_{2}}\right]
$$

式（12）により求まる拡散係数は $x$ 方向に分布をも つが,ここでは $x=0.5 w$ の值により代表させた. とこ ろで式（12）により拡散係数を計算して実験值と比較す ると， $x$ をどのような值にしてもすべての実験值に合わ せることができない．これは $x=$ 一定と仮定したことに

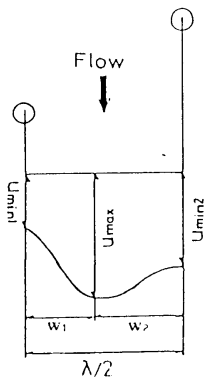

Fig. 10 Definition Sketch of Wake Flow Behind Staggered Roughness Bars. 


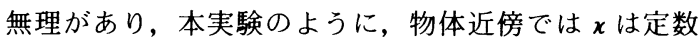
とは断じがたく，式 $(2)$ と同様に無次元数 $d / \lambda, \omega / \lambda$ の関数であると考えられる，そこで式 (12) から流速分 布表示式と㹡散実験結果より $x$ を求め, 無次元数 $d / \lambda$,

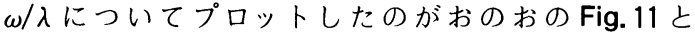
Fig. 12 である.これらの図から $x$ は二無次元数のおの おのについて，ほぼべき乗に比例すると結論され，結局 次式のように表わされる.

$x=4.0(d / \lambda)^{1.5}(\omega / \lambda)^{0.75}$.

式 $(10),(12),(13)$ を用いて $\varepsilon$ を計算し，実験值と 比較したのがFig. 13 である. 当然ながら実験值と計算 值は良好な一致を示しているが， $d / \lambda$ と $\omega / \lambda$ の双方に 関してその一致が得られたということは，ここで導かれ た計算式の有用性が広いことを示唆している.

Fig. 14 は $d / \lambda$ の種々の値に対して Fig. 13 を書き直し たものである. Fig. 14 でわかるように $\varepsilon / \lambda U$ は $\omega / \lambda$ に ほとんどよらない.そこで $d / \lambda$ の関数として表わした のが，Fig. 15 であり，これら両図を用いることにより， 任意の $d / \lambda, \omega / \lambda$ の選択に対して水平拡散係数を求める ことができる.なお Fig. 14，15の曲線は実験結果でほ ぼ確かめられた範用内で描いているものであり，実用的

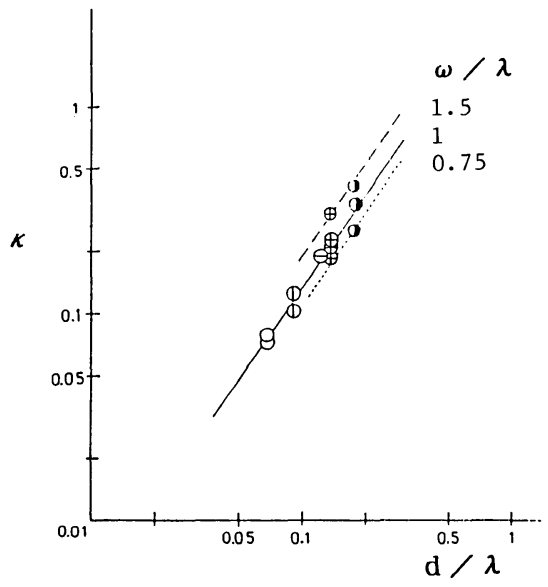

Fig. 11 Relationship Between $x$ and $d / \lambda$.

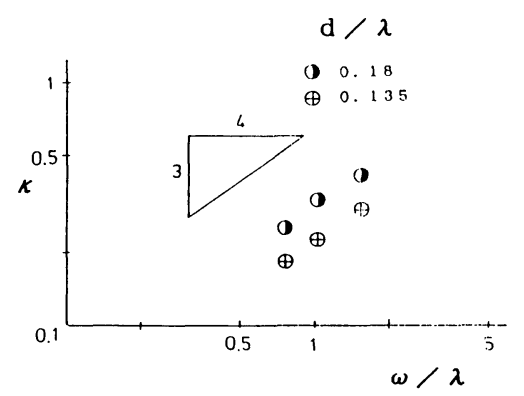

Fig. 12 Relationship Between $x$ and $\omega / \lambda$.
には十分な範囲であると思われる.

\section{5. 応用 例}

本研究で得られた柱状粗度のある流れの水平拡散係数 の計算図表 Fig. 14，15を，実際の二次元潮汐水理模型

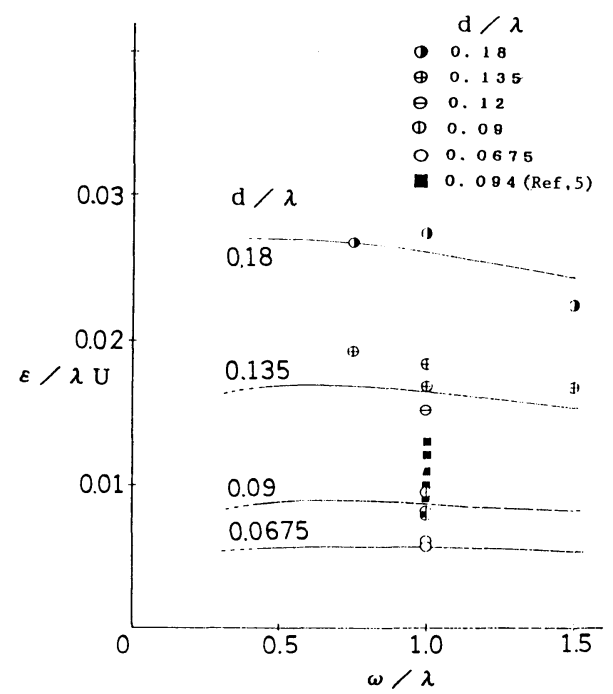

Fig. 13 Measured Diffusivity versus Prediction.

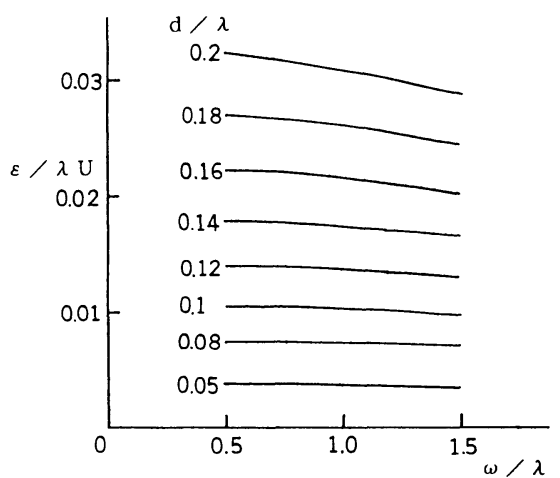

Fig. 14 Dimensionless Diffusivity versus $\omega / \lambda$.

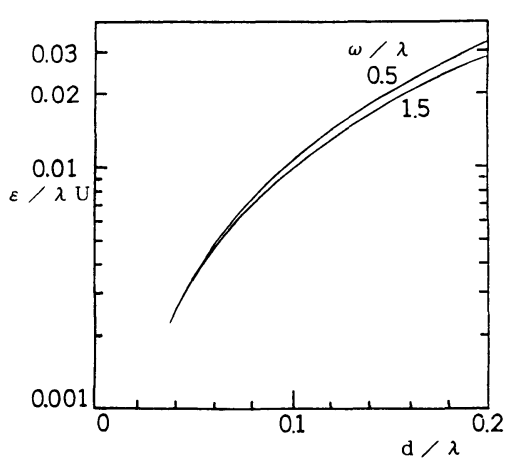

Fig. 15 Dimensionless Diffusivity versus $d / \lambda$. 
の例に適用してみる. 大型の潮汐水理模型は近年，瀬戸 内海, 大阪湾, 伊勢湾, 東京湾, などの例が報じられて いるが，ここでは，柱状粗度を使用し，拡散係数の現地 観測が多く報じられている例として, 運輸省の行った大 阪湾の例を取り上げる ${ }^{8)}$.この模型は他の多くの模型と 同様に，リチャードソン・オズミドフ則による相似則を 満たすように，水平縮尺 $1 / 2000$, 鉛直縮尺 $1 / 160$ が採 用されている. 柱状粗度は直径 $2.5 \mathrm{~cm}$ の塩化ビニール パイプを $50 \mathrm{~cm}$ 格子で配置してある.

潮汐水理模型では流向が場所の関数であるとともに， 刻々変化する時間の関数でもある. したがってこの場合 も格子状に配置された粗度群に対して流向を特定するこ とはできないが, 本研究の成果を応用して一応の目安と しての拡散係数を求めるために, 粗度群が千鳥状にみえ るように流れているものと仮定する. そうすると $\lambda=$ $70.7 \mathrm{~cm}, \omega=35.4 \mathrm{~cm}$ となり, Fig. 15 より $\varepsilon / \lambda U=$ 0.0021 を得る. 代表流速 $U$ としては, 大阪湾中の潮流 のやや早めの地点の現地平均流速として $30 \mathrm{~cm} / \mathrm{s}$ を採用 すると現地換算で $\varepsilon=0.9 \times 10^{4} \mathrm{~cm}^{2} / \mathrm{s}$ が得られ，この值 は同報告書掲載の現地観測による挔散係数の值 $3 \times 10^{3}$ 〜 $3 \times 10^{5} \mathrm{~cm}^{2} / \mathrm{s}$ の範囲の中にある. またもし粗度なしで 実験を行ったと考え, 拡散係数が $0.15 h u_{*}$ で与えられ, マニングの平均流速公式が成立すると仮定すると, 現地 拡散係数は次式のように計算される.

$$
\begin{aligned}
\varepsilon & =0.15 h u_{*}=0.15 n g^{1 / 2} U h^{5 / 16} \\
& =1.1 \times 10^{3} \mathrm{~cm}^{2} / \mathrm{s}
\end{aligned}
$$

ただし， $n=0.01 ， h=20 \mathrm{~m}$ とした.これより粗度を付 加することにより, 昖散現象の相似性が確保されたもの と結論づけることができる.

\section{6. 結 論}

柱状粗度を用いた拡散現象の相似技術の確立のために 粗度による拡散効果を, 理論的実験的に明らかにした. その結果, 柱状粗度のある流れの拡散係数は, 式 (10), (12)，（13）またはFig. 14，15を用いて表わされること が示された。この結果は実際の水理模型の例に関しても 適用されることを示した。

謝辞：本研究を進めるにあたり，長岡技術科学大 学大学院生 香川健一君の多大な協力があったことをこ こに記して謝意を表する。

\section{参 考 文 献}

1）早川典生：水質環境予測のための潮汐水理模型実験, 産 業公害, Vol. 20, No. 3, pp. 19 34, 1985.

2）樋口明生 : 沿岸海洋に関する水理模型実験, 水工学シリ一 ズ B, 土木学会, pp. B-9-1 B-9-23, 1972.

3) Crickmore, M. J. : Tracer Tests of Eddy Diffusion in the Field and Model, J. of Hyd. Div., Proc. ASCE, Vol. 98, pp. $1737 \sim 1752,1972$.

4) Fischer, H. B. : Mixing and Dispersion in Estuaries, Ann. Rev. Fluid Mech., Vol. 8, pp. 107 134, 1976.

5) Fischer, H. B. and Hanamura, T. : The Effect of Roughness Strips on Transverse Mixing in Hydraulic Models, Water Resources Research, Vol. 11, No.2, pp. 362 364, 1975.

6) Hinze, J. O. : Turbulence, Second Ed., McGraw-Hill, 1975.

7) Schlichting, H. : Boundary Layer Theory, Seventh Ed., McGraw-Hill, 1979.

8）運輸省第三港湾建設局神戸調查設計専，務所：土砂による 海水污濁の予測手法（通年報告書）昭和 55 年 3 月, 1980. 